\title{
KATA MAJEMUK DALAM TEKS BERITA DARING CNN INTERNATIONAL EDISI SEPTEMBER 2019: KAJIAN MORFOLOGI
}

\author{
(Compounding in CNN International Online Newspaper September, 2019: \\ Morphological Studies)
}

\section{Syifa Wasilatul Fauziyah}

Fakultas Ilmu Budaya Universitas Padjajaran

Jalan Raya Bandung-Sumedang Km.21

Hegarmanah, Jatinangor, Sumedang, Jawa Barat 45365

Posel: Syifawasilatulfauziyah_unpad@yahoo.com

(Naskah Diterima Tanggal 21 November 2019-Direvisi Tanggal 28 Februari 2020_-Disetujui Tanggal 9 Maret 2020)

\begin{abstract}
Abstrak
Penelitian ini berjudul "Kata Majemuk dalam Teks Berita Daring CNN International Edisi September 2019: Kajian Morfologi”. Penelitian ini bertujuan untuk mengetahui bentuk dan kategori kata majemuk dalam teks berita daring CNN International edisi Sepember 2019. Metode yang digunakan dalam penelitian ini adalah metode kualitatif-deskriptif. Data dalam penelitian ini diperoleh dengan cara membaca berita daring CNN International bulan September tahun 2019. Hasil dalam penelitian ini menunjukkan bahwa proses compounding dalam teks berita daring CNN International edisi Sepember 2019 dapat diklasifikasikan pada dua bentuk yang terdiri dari bentuk tulisan dan bentuk kata majemuk. Berdasarkan bentuk tulisan didapati dua bentuk tulisan yaitu close form (bentuk tertup) dan open form (bentuk terbuka), kemudian berdasarkan bentuk kata mejemuknya didapati dua bentuk, yaitu berbentuk endocentic compound (memiliki inti kata) dan excocentric compound (tidak memiliki inti kata). Kategori kata dalam teks berita daring CNN International edisi Sepember 2019, didapati dua katgori kata majemuk, yaitu kata majemuk yang berkategori nomina (nomina+nomina/verba+nomina) dan kata majemuk yang berkategori verba (nomina+verba).
\end{abstract}

Kata Kunci: Morfologi, kata majemuk; berita daring.

\begin{abstract}
The title of this research is "Compounding in CNN International Online Newspaper September, 2019: Morphological Studies". this research aims to describe the compounding form and compounding category in CNN Internatinal online newspaper, September 2019. The method in this research is used qualitative descriptive research method. The data in this research were obtined by reading the CNN Internatinal online newspaper, September 2019. The result of this research shows that the compounding process in CNN Internatinal online newspaper, September 2019 can be classified into two forms they are writing forms and compounding forms. In writing forms they are open form and close form and the form of compounding they are endocentric compound (which has a head of compound words) and exocentric compound (which has no a head of a compound word). The category of the data they are compound noun (noun+noun/verb+noun) and compound verb (noun+verb).
\end{abstract}

Keyword: morfologi; compounding; online newspaper.

\section{PENDAHULUAN}

Bahasa merupakan lambang bunyi arbiter mengidentifikasi diri. Setiap manusia yang digunakan untuk berkomunikasi serta menggunakan bahasa sebagai sarana komunikasi antar sesama. Satu di antara 
contohnya adalah bahasa yang digunakan di media massa. Media massa menggunakan bahasa sebagai sarana untuk menyampaikan berita-berita yang ada di dunia. Menurut Halliday \& Hasan (1992: 13) teks berita merupakan sebuah teks yang berkaitan dengan hal yang aktual 'dilakukan' ;dimaknai' dan 'dikatakan oleh masyarakat dalam sebuah situasi yang nyata. Senada dengan hal itu, Santoso (2012: 65) menjelaskan bahwa teks berita merupakan sebuah modus wacana, sebuah teks yang dihasikan mungkin saja berasal dari sebuah wacana yang itu semua berakar pada kondisi-kondisi sosial, ekonomis, politis, dan ideologis. Teks berita merupakan teks yang melaporkan kejadian, peristiwa atau informasi mengenai sesuatu yang telah atau sedang terjadi dan berisi tentang fenomena yang secara faktual yang biasanya berakar dari kondisi-kondisi seperti sosial, ekonomi, politis dan ideologis. Teks berita merupakan hal yang sangat penting karena dapat memberikan informasi-informasi yang ada, sehingga para pembaca akan mengatahui apa yang sedang terjadi di dunia ini.

Pada zaman modern ini, teks berita akan lebih mudah untuk di dapatkan, karena seiring berkembangnya teknologi, teks beritapun dapat dibaca melalui berbagai situs daring. Satu di antara contohnya, yaitu teks berita dalam situs daring $\mathrm{CNN}$ International. CNN merupakan singkatan dari Cable News Network yang merupakan satu diantara situs berita yang sangat terkenal, yang memuat segala informasi melalui situs daring. Pemberitaan dalam CNN International menggunakan bahasa Inggris karena berita yang dimuat merupakan informasi yang ada di berbagai belahan dunia. Dalam menulis sebuah berita, para jurnalis selalu menggunakan kata-kata yang unik seperti memainkan kata, frasa atau kalimat untuk menarik minat para pembaca.

Penelitian ini akan meneliti tentang kata majemuk dalam teks berita $\mathrm{CNN}$ International. Penelitian tentang kata majemuk menarik untuk diteliti karena kata majemuk merupakan pembentukan sebuah istilah baru yang terdiri atas dua morfem bebas. Penelitian ini terinspirasi dari penelitian terdahulu, yaitu "Penggunaan Konjungsi dalam Surat Kabar Republika Online Edisi Maret-Mei 2018: Suatu Kajian Sintaksis" yang ditulis oleh Cendramata (2018). Penelitian itu meneliti tentang penggunaan Konjungsi dalam wacana Surat Kabar Online Republika. "Konseptualisasi Metafora dalam Rubik Opini Kompas: Kajian Semantik Kognitif" yang ditulis oleh Baiq Haula, meneliti tentang jenis-jeni metafora dan skema citra yang ada dalam rubik opini Kompas, dan yang ketiga yaitu "Analisis Wacana Kritis Pemberitaan Saweran untuk Gedung KPK di Harian Umum Media Indonesi" yang ditulis oleh Mayasari, dll. meneliti tentang Representasi, aspek kebahasaan, hubungan antara Ideologi dengan Masyarakat, dan mendeskripsikan situasi pilitik atau sosial yang ada. Dalam penelitian ini difokuskan untuk meneliti kata majemuk dalam teks berita daring CNN International edisi bulan September 2019. Penelitian ini merupakan penelitian kajian linguistik, yaitu morfologi.

Morfologi merupakan cabang ilmu linguistik yang mempelajari tentang seluk beluk sebuah morfem Yule (2016: 67). Menurut Katamba \& Stonham (2006: 4) morfologi merupakan ilmu bahasa yang mempelajari struktur internal dari sebuah kata. Lebih lanjut, O'Grady \& Archibald (2015: 100) mengemukakan bahwa morfologi suatu cabang linguistik yang mempelajari tentang seluk beluk kata atau proses pembentukan sebuah kata. Dari ketiga pendapat itu, dapat disimpulkan bahwa morfologi merupakan satu di antara cabang linguistik yang mempelajari seluk beluk sebuah kata, stuktur internal kata, dan proses pembentukan kata. Adapun proses pembentukan kata yang akan dikaji dalam penelitian ini, yaitu proses morfologis kata majemuk pada teks berita daring $\mathrm{CNN}$ International edisi Sepember 2019. Yule (2016: 55) berpendapat bahwa kata majemuk merupakan bagian dari proses 
morfologis yaitu proses yang menggabungkan dua morfem bebas untuk membentuk satu istilah baru dan memiliki makna baru. Senada dengan hal itu, Lieber (2007: 43) berpendapat bahwa kata majemuk merupakan proses pembentukan kata baru yang terdiri atas dua morfem bebas. Katamba dan Stonham (2006: 55) berpendapat bahwa kata majemuk merupakan proses pembentukan suatu istilah baru yang terdiri atas dua morfem yang berbeda. Dari ketiga pendapat itu, dapat disimpulkan bahwa kata majemuk merupakan proses morfologis yang menggabungkan dua morfem bebas untuk membentuk suatu istilah yang baru dan memiliki makna baru. dalam bahasa Inggris kata majemuk memiliki beberapa ciri, di antaranya adalah sebagai berikut.

a. Bentuk kata majemuk dalam bahasa Inggris menurut Plag (2003: 186--188) terdiri atas tiga bagian, yaitu endocentric compound, exocentric compound, dan copulative compound. Endocentric compound merupakan kata majemuk yang memiliki satu initi kata (head) untuk menentukan makna dari kata majemuk itu, contohnya pada kata air plane yaitu pesawat yang dikemudikan di udara atau fire truck, yaitu truk atau kenaraan pemadam kebakaran. Kedua, exocentric compound merupakan kata majemuk yang tiak memiliki inti kata untuk mengetahui makna dari kata majemuk itu. Senada dengan itu, exocentric compound merupakan sebuah makna yang baru yang tidak mempertahankan makna aslinya (Katamba dan Stonham, 2006: 306). Contoh dari bentuk exocentric compound seperti pada kata redneck, kata redneck bukan mengacu pada orang yang memiliki leher berwarna merah tetapi redneck mengacu pada istilah yang digunakan untuk menghina orang- orang yang berkulit putih yang bekerja dan tinggal di sebuah pedesaan khususnya orang-orang yang tinggal di daerah Amerika selatan. Ketiga, yaitu compulative compound sebuah bentuk kata majemuk yang memiliki dua inti kata untuk mengetahui makna yang ada dari kata majemuk itu, contohnya pada kata singer-song writer yang memiliki makna seorang penyanyi dan penulis lagu.

b. Kata majemuk dalam bahasa Inggris dapat dibedakan dari bentuk tulisannya. Menurut Katamba dan Stonham (dalam Cahyanti, 2016: 61) bentuk tulisan kata majemuk dalam bahasa Inggris dapat dibedakan menjadi open form, close orm, dan hypnated form. Pertama, bentuk open form merupakan bentuk tulisan kata mejemuk yang ditulis sebagai kata terpisah, contohnya seperti pada kata fire truck, air plane. Kedua, kata majemuk yang ditulis dengan bentuk close form, yaitu kata majemuk yang ditulis sebagai sebuah kata tunggal, contohnya pada kata redneck dan yang terakhir hypnated form, yaitu kata majemuk yang ditulis dengan menambahkan kata penghubung di antara dua kata yang menjadi bagian dari kata majemuk itu, contohnya pada kata sister-in-law.

c. Menurut Katamba dan Stonham (2006: 309) kata majemuk dalam bahasa Inggris memiliki kategori kata di antaranya compound noun, verb dan adjective. Kata majemuk dalam bahasa Inggris merupakan kombinasi dari nomina, verba dan adjektiva, biasanya morfem sebelah kanan dapat menentukan kategori kata majemuk, namun beberapa kategori kata majemuk dapat ditentukan oleh morfem yang sebelah kiri. Kategori kata 
majemuk terdiri atas kata majemuk nomina, verba, dan ajektiva. Kata majemuk nomina, verba, ajektiva dapat terbentuk dari kata-kata yang memiliki kategori-kategori yang berbeda. Hal yang terpenting adalah setelah kedua kata itu digabungkan akan mengacu pada kategori kata nomina, verba atau ajektiva. Kombinasi kategori kata yang dapat membentuk kata majemuk nomina, verba, dan ajektiva di antaranya:

1) nomina + nomina $=$ football, bed cover, bus stop (nomina);

2) nomina + verba = roadshow, milkshake, rainfall (nomina);

3) nomina + ajektiva $=$ snow white (nomina);

4) nomina + frasa preposisi = mother-in-law, hanger on (nomina);

5) verba + nomina $=$ dance floor, swimming pool (nomina);

6) adjektiva + verba $=$ public speaking, (nomina);

7) verba + verba $=$ make believe (nomina);

8) noun + verb $=$ breast feed (verba);

9) ajektiva + ajektiva $=$ bittersweet, deaf-mute (adjektiva).

d. Menurut Plag (2000: 175) kata majemuk dalam bahasa Inggris memiliki pola pengucapan. Hal itu merupakan satu di antara pembeda antara kata majemuk dengan sebuah frasa. Untuk kata majemuk pola pengucapan di tekankan pada morfem yang terletak di sebelah kiri, sedangkan untuk frasa pola pengucapan ditekankan pada morfem yang terakhir. Contohnya 'blackbird (kata majemuk), black bird' (frasa), 'blackboard (kata majemuk), black board' (frasa).

\section{METODE}

Penelitian ini menggunakan metode deskriptif kualitatif. Menurut Djajasudarma (2010: 10) metode penelitian kualitatif merupakan sebuah metode yang menghasilkan data deskriptif dalam masyarakat bahasa, data itu dapat berbentuk data tertulis atau data lisan. Lebih lanjut, Djajasudama (2010: 9) menjelaskan bahwa metode deskriptif bertujuan membuat deksripsi data; maksudnya untuk memberikan penjelasan atau menggambarkan secara faktual, sistematis, dan akurat mengenai sifat-sifat atau hubungan fenomena-fenomena pada data yang akan diteliti. Metode itu bertujuan untuk mendeskripsikan bentuk kata majemuk pada teks berita CNN International. Selanjutnya, data dikumpulkan dengan menggunakan teknik simak bebas libat cakap dan teknik catat. Teknik lanjutan simak bebas libat cakap menurut Sudaryanto (2015: 203) merupakan metode yang dilakukan dengan tidak terlibat dalam dalam dialog atau wawancara, karena untuk pengambilan data dalam penelitian ini penulis membaca berita-berita daring pada situs berita CNN International, kemudian penulis mencatat data-data yang berupa kata kata majemuk yang terdapat pada berita-berita itu. Metode analisis yang digunakan dalam penelitian ini yaitu metode agih dengan teknik dasar teknik BUL. Metode agih merupakan cara menganalisis data yang alat penelitiannya berada dalam bahasa yang bersangkutan itu sendiri (Sudaryanto, 2015: 18). Teknik yang dipilih adalah teknik dasar yaitu teknik BUL. Menurut Sudaryanto (2015: 37) teknik bagi unsur langsung atau teknik BUL merupakan teknik analisis yang digunakan untuk membagi data menjadi beberapa bagian yaitu untuk membentuk satuan lingual yang dimaksud. Berdasarkan tujuan penelitian, untuk memberikan data yang relevan, penulis menggunakan teknik bagi unsur langsung (BUL) untuk menganalisis kata majemuk. pada teks berita yang ada dalam situs daring 
CNN International, dengan teknik BUL penulis dapat memilah-milah bentuk kata majemuk, bentuk tulisan, atau kategori kata yang ada pada data-data kata majemuk yang telah dilampirkan.

\section{PEMBAHASAN Close form Compounds}

\section{(1) Whistleblower}

"Miller argued it's actually Trump who is the whistleblower because he has uncovered a government run amok and as a result his presidency has suffered from three years of "deep state sabotage".

(https://edition.cnn.com/2019/09/28/poli tics/whistleblower-deep-state-trumpimpeachment-inquiry/index.html)

Pada data 1, secara morfologis whisleblower merupakan kata majemuk. Proses kata majemuk pada istilah whistleblower dibentuk dengan cara menggabungkan dua morfem bebas dan satu morfem terikat. Proses morfologisnya yaitu, kata whistle digabungkan dengan kata blow menjadi whistleblow kemudian kata blow digabungkan dengan afiks -er menjadi blower. Setelah kedua kata itu digabungkan menjadi whistleblower istilah itu memiliki makna baru dari makna sebelumnya. Whistleblower merupakan kata majemuk yang ditulis dengan bentuk close form, karena whistleblower ditulis sebagai kata tunggal. Berdasarkan bentuknya, whistleblower merupakan kata majemuk exocentric compound, karena whistleblower tidak memiliki inti kata, untuk mengetahui makna yang ada. Whistle blower merupakan seseorang yang memberitahu pihak yang berwenang akan terjadinya sesuatu yang ilegal, terutama dalam departement pemerintahan atau perusahaan. Diklasifiksikan sebagai exocentric compound karena jika dilihat dari makna yang didapat dari unsur-unsur pembentuknya, whistleblower tidak memiliki inti kata untuk mengetahui makna yang ada. Selain secara bentuk, yang dapat menentukan makna kata majemuk whistleblower, kata whistleblower dapat dikaji secara kategori katanya. Berdasarkan kategori kata, whistleblower memiliki kategori nomina, karena terbentuk dari kata whistle yang memiliki kategori verba dan kata blower yang memiliki kategori nomina.

\section{(2) Pickpocketing}

"If that is indeed what happened, and the signs strongly suggest it is, then Trump's behavior makes Watergate look like petty pickpocketing".

(https://edition.cnn.com/2019/09/24/opi nions/did-trump-betray-his-countryghitis/index.html)

Pada data 2, secara morfologis pickpocketing merupakan kata majemuk. Proses kata majemuk pada istilah pickpocketing dibentuk dengan cara menggabungkan dua morfem bebas dan satu morfem terikat. Proses morfologisnya yaitu, kata pick digabungkan dengan kata pocket menjadi pickpocket kemudian kata pocket digabungkan dengan afiks -ing menjadi pocketing. setelah kedua kata itu digabungkan menjadi pickpocketing istilah itu memiliki makna baru dari makna sebelumnya. Pickpocketing merupakan kata majemuk yang ditulis dengan bentuk close form, karena pickpocketing ditulis sebagai kata tunggal. Berdasarkan bentuknya, pickpocketing merupakan kata majemuk endocentric compound, karena pickpocketing memiliki inti kata, untuk mengetahui makna yang ada. Adapun inti kata itu terletak pada morfem yang sebelah kanan, yaitu pocket. Pickpocketing merupakan seorang pencuri yang biasanya mencuri barang dari dompet atau tas seseorang yang biasanya dilakukan dalam keramaian yang berdesak-desakan. Selain secara bentuk, yang dapat menentukan makna kata majemuk pickpocketing, kata pickpocketng dapat dikaji secara kategori katanya. Berdasarkan kategori kata, pickpocketing memiliki kategori nomina, karena terbentuk dari kata pick yang memiliki kategori verba dan kata pocketing yang memiliki kategori nomina. kata pick 
berkategori verba karena mengacu pada sebuah aktivitas dan kata pocketing berkategori nomina karena mengacu pada seseorang atau pelaku.

\section{(3) Watergate}

"If that is indeed what happened, and the signs strongly suggest it is, then Trump's behavior makes Watergate look like petty pickpocketing".

(https://edition.cnn.com/2019/09/24/opi nions/did-trump-betray-his-countryghitis/index.html)

Pada data 3, secara morfologis watergate merupakan kata majemuk. Proses kata majemuk pada istilah watergate dibentuk dengan cara menggabungkan dua morfem bebas. Proses morfologisnya yaitu, kata water digabungkan dengan kata gate menjadi watergate. Setelah kedua kata itu digabungkan menjadi watergate istilah itu memiliki makna baru dari makna sebelumnya. Watergate merupakan kata majemuk yang ditulis dengan bentuk close form, karena watergate ditulis sebagai kata tunggal. Berdasarkan bentuknya, watergate merupakan kata majemuk exocentric compound, karena watergate tidak memiliki inti kata, untuk mengetahui makna yang ada. Watergate merupakan skandal politik yang menyebabkan penyalahgunaan kekuasaan atau kasus suap menyuap yang menghalangi keadilan. Istilah wategate ini mengacu pada sejarah Amerika pada tahun 1972-1974, yaitu terjadinya skandal politik yang sangat besar, skandal yang melengserkan presiden Richard Nixon tahun 1974. Selain secara bentuk, yang dapat menentukan makna kata majemuk watergate, kata watergate dapat dikaji secara kategori katanya. Berdasarkan kategori kata, watergate memiliki kategori nomina, karena watergate terdiri atas dua morfem yang memiliki kategori kata nomina.

\section{(4) Firefighter}

"The skirmishes with authorities that followed injured four police offiscers and a firefighter, police said, while the Greek
Ministry of Health said that 17 people were hospitalized with minor injuries and breathing problems".

(https://edition.cnn.com/2019/09/30/eur ope/lesbos-moria-refugee-camp-greecefire-riots-intl/index.html)

Pada data 4, secara morfologis firefighter merupakan kata majemuk. Proses kata majemuk pada istilah firefighter dibentuk dengan cara menggabungkan dua morfem bebas dan satu morfem terikat. Proses morfologisnya yaitu, kata fire digabungkan dengan kata figh menjadi firefigh kemudian kata figh digabungkan dengan afiks -er menjadi fighter. Setelah kedua kata itu digabungkan menjadi firefighter istilah itu memiliki makna baru dari makna sebelumnya. Firefighter merupakan kata majemuk yang ditulis dengan bentuk close form, karena firefighter ditulis sebagai kata tunggal. Berdasarkan bentuknya, firefighter merupakan kata majemuk endocentric compound, karena firefighter memiliki satu inti kata untuk mengetahui makna yang ada. Adapun inti kata itu terletak pada kata fire. Firefighter merupakan profesi pemadam kebakan. Selain secara bentuk, yang dapat menentukan maknanya, kata firefighter dapat dikaji secara kategori katanya. Berdasarkan kategori kata, firefighter memiliki kategori nomina, karena firefighter terdiri atas dua morfem yang memiliki kategori kata nomina. Morfem fire yang berkategori nomina dan morfem fighter yang juga berkategori nomina.

\section{(5) Crowdstrike}

"Founded in 2011, Crowdstrike sells its "Falcon" cybersecurity software to big corporations and government clients, including major global banks, healthcare and energy companies, according to the company. Among its customers are Goldman Sachs, Amazon Web Services, MIT and various US states and cities. Crowdstrike says Falcon protects files saved in the cloud. The company also helps run cybersecurity investigations for the US government. For example, Crowdstrike has tracked 
North Korean hackers for more than a decade, the company says".

(https://edition.cnn.com/2019/09/26/tec

$\mathrm{h} /$ what-is-crowdstrike/index.html)

Pada data 5, secara morfologis crowdstrike merupakan kata majemuk. Proses kata majemuk pada istilah crowdstrike dibentuk dengan cara menggabungkan dua morfem bebas. Proses morfologisnya yaitu, kata crowd digabungkan dengan kata strike menjadi crowdstrike. Setelah kedua kata itu digabungkan menjadi trash-talk istilah itu memiliki makna baru dari makna sebelumnya. Crowdstrike merupakan kata majemuk yang ditulis dengan bentuk close form, karena crowdstrike ditulis sebagai kata tunggal. Berdasarkan bentuknya, crowdstrike merupakan kata majemuk exocentric compound, karena crowdstrke tidak memiliki inti kata, untuk mengetahui makna yang ada. Crowdstrike merupakan sebuah perusahaan yang berasal dari Amerika dan bergerak dalam bidang keamanan cyber, perusahaan itu menjual perangkat lunak keamanan kepada klien pemerintahan atau perusahaan-perusahaan besar untuk melindungi data dari perusahaan itu. Selain secara bentuk, yang dapat menentukan maknanya, kata crowdstrike dapat dikaji secara kategori katanya. Berdasarkan kategori kata, crowdstrike memiliki kategori verba, karena crowdsstrike terdiri atas morfem crowd yang memiliki kategori kata nomina dan morfem strike yang memiliki kategori verba.

\section{(6) Moonwalk}

"That first viral video collected 22.7 million views, and additional videos of Spot have continued to draw millions of views over the years. After all, this is a robot dog who cantwerk and moonwalk, and who won over sympathy on social media when the company released a video of researchers kicking the dog to demonstrate its balance".

(https://edition.cnn.com/2019/09/25/app -tech-section/robot-dog-sale-intl-hnkscli/index.html)
Pada data 6, secara morfologis moonwalk merupakan kata majemuk. Proses kata majemuk pada istilah moonwalk dibentuk dengan cara menggabungkan dua morfem bebas. Proses morfologisnya yaitu, kata moon digabungkan dengan kata walk menjadi moonwalk. Setelah kedua kata itu digabungkan menjadi moonwalk istilah itu memiliki makna baru dari makna sebelumnya. Moonwalk merupakan kata majemuk yang ditulis dengan bentuk close form, karena moonwalk ditulis sebagai kata tunggal. Berdasarkan bentuknya, moonwalk merupakan kata majemuk endocentric compound, karena moonwalk memiliki satu inti kata, untuk mengetahui makna yang ada. Adapun inti kata itu terletak pada kata walk. Moonwalk merupakan sebuah tarian terkenal yang dikenalkan oleh penyanyi terkenal Amerika yaitu Michele Jacson. Teknik menari moonwalk merupakan sebuah tarian yang memiliki gaya ketika sang penari menari, tubuhnya seperti ditarik ke bagian belakang sedangkan si penari berusaha berjalan kedepan. Selain secara bentuk, yang dapat menentukan maknanya, kata moonwalk dapat dikaji secara kategori katanya. Berdasarkan kategori kata, moonwalk memiliki kategori verba, karena moonwalk terdiri atas morfem moon yang memiliki kategori kata nomina dan morfem walk yang memiliki kategori verba.

\section{(7) Weatherman}

"it seems like Iger carried this lesson with him throughout his career. After failing as a weatherman at a local TV station in New York, Iger ended up in production at $A B C$ where he met mentors like Arledge, Burke, and Murphy". (https://edition.cnn.com/2019/09/30/me dia/bob-iger-amanpour/index.html)

Pada data 7, secara morfologis weatherman merupakan kata majemuk. Proses kata majemuk pada istilah weatherman dibentuk dengan cara menggabungkan dua morfem bebas. Proses morfologisnya yaitu, kata weather digabungkan dengan kata man 
menjadi weatherman. Setelah kedua kata itu digabungkan menjadi moonwalk istilah itu memiliki makna baru dari makna sebelumnya. Weatherman merupakan kata majemuk yang ditulis dengan bentuk close form, karena weatherman ditulis sebagai kata tunggal. Berdasarkan bentuknya, weatherman merupakan kata majemuk endocentric compound, karena weatherman memiliki satu inti kata, untuk mengetahui makna yang ada. Adapun inti kata itu terletak pada morfem sebelah kanan yaitu morfem man. Weatherman merupakan seorang penyiar $\mathrm{TV}$ atau radio yang menyampaikan ramalan tentang keadaan cuaca. Selain secara bentuk, yang dapat menentukan maknanya, kata weatherman dapat dikaji secara kategori katanya. Berdasarkan kategori kata, weatherman memiliki kategori nomina, karena weatherman terdiri atas morfem weather yang memiliki kategori kata nomina dan morfem man yang juga memiliki kategori kata nomina.

\section{(8) Groundbreaking}

"Iger said he "quickly discovered that the right people were at Pixar," the acclaimed animation studio behind the groundbreaking "Toy Story" franchise that was chaired by Steve Jobs".

(https://edition.cnn.com/2019/09/30/me dia/bob-iger-amanpour/index.html)

Pada data 8, secara morfologis groundbreaking merupakan kata majemuk. Proses kata majemuk pada istilah groundbreaking dibentuk dengan cara menggabungkan dua morfem bebas dan satu morfem terikat. Proses morfologisnya yaitu, kata ground digabungkan dengan kata break menjadi groundbreak kemudian kata break digabungkan dengan afiks -ing menjadi braking. Setelah kedua kata itu digabungkan menjadi groundbreaking istilah itu memiliki makna baru dari makna sebelumnya. Groundbreaking merupakan kata majemuk yang ditulis dengan bentuk close form, karena groundbreaking ditulis sebagai kata tunggal. Berdasarkan bentuknya, groundbreaking merupakan kata majemuk exocentric compound, karena groundbreaking tidak memiliki inti kata, untuk mengetahui makna yang ada. groundbreaking merupakan sebuah acara peresmian dari sebuah proyek yang telah dilakukan. Selain secara bentuk, yang dapat menentukan makna kata majemuk groundbreaking, kata groundbreaking dapat dikaji secara kategori katanya. Berdasarkan kategori kata, grooundbreaking memiliki kategori verba, karena terbentuk dari kata ground yang memiliki kategori nomina dan kata breaking yang memiliki kategori verba.

\section{Open Form Compounds}

(9) Witch hunt
"President Donald Trump has long
complained of a deep state of
bureaucrats out to get him. He's argued
that investigations into his unsettling
activity are nothing more than witch
hunts".
(https://edition.cnn.com/2019/09/28/poli
tics/whistleblower-deep-state-trump-
impeachment-inquiry/index.html)

Pada data 2, secara morfologis witch hunt merupakan kata majemuk atau dalam bahasa Indonesia disebut kata majemuk. Proses kata majemuk pada istilah witch hunt dibentuk dengan cara menggabungkan dua morfem bebas, yaitu morfem witch dan morfem hunt. Setelah kedua kata itu digabungkan menjadi witch hunt kata itu memiliki makna baru dari makna sebelumnya, Witch hunt merupakan kata majemuk yang ditulis dengan benuk open form (bentuk terbuka), karena witch hunt ditulis sebagai kata terpisah. Berdasarkan bentuknya, witch hunt merupakan kata majemuk endocentric compound, karena witch hunt memiliki satu inti kata untuk mengetahui makna yang ada. Inti kata itu terletak pada morfem hunt. Witch hunt merupakan mencari-cari kesalahan, dari konteks pemberitaan yang ada yang biasanya ditemukan dalam dunia politik sebagai peringatan adanya tuduhan- 
tuduhan palsu atau proses hukum yang tidak berjalan dengan lancar. Selain secara bentuk, yang dapat menentukan makna kata majemuk witch hunt, kata witch hunt dapat dikaji secara kategori katanya. Berdasarkan kategori katanya, witch hunt merupakan verba karena terdiri atas kata witch yang berkategori nomina dan kata hunt yang berkategori verba.

\section{Hypnated Form Compounds}

\author{
(10) Trash-talk \\ "Trump then trash-talks German \\ Chancellor Angela Merkel, saying that \\ "...she talks Ukraine, but she doesn't do \\ anything". \\ (https://edition.cnn.com/2019/09/25/opi \\ nions/trump-code-talk-ukraine- \\ callan/index.html)
}

Pada data 10, secara morfologis trash-talk merupakan kata majemuk. Proses kata majemuk pada istilah trash-talk dibentuk dengan cara menggabungkan dua morfem bebas. Proses morfologisnya yaitu, kata trash digabungkan dengan kata talk menjadi trash-talk. Setelah kedua kata itu digabungkan menjadi trash-talk istilah itu memiliki makna baru dari makna sebelumnya. Trash-talk merupakan kata majemuk yang ditulis dengan bentuk hypnated form, karena trash-talk ditulis dengan menggunakan tanda penghubung. Berdasarkan bentuknya, trash-talk merupakan kata majemuk endocentric compound, karena trash-talk memiliki satu inti kata, untuk mengetahui makna yang ada. Adapun inti kata itu terletak pada kata talk. Trash-talk merupakan bentuk ujaran

\section{DAFTAR PUSTAKA}

Cahyanti, R. D. (2016). Compound Words Used in Stephanie Meyer's Twilight. Journal on English as Foreign Language, 6(2), 61--66.

Cendramata, R. C. (2018). Penggunaan Konjungsi Dalam Surat Kabar atau pembicaraan penghinaan, trash-talk biasanya dilakukan untuk melawan atau mengintimidasi seseorang. Selain secara bentuk, yang dapat menentukan maknanya, kata trash-talk dapat dikaji secara kategori katanya. Berdasarkan kategori kata, trashtalk memiliki kategori verba, karena trashtalk terdiri atas morfem trash yang memiliki kategori kata nomina dan morfem talk yang memiliki kategori verba.

\section{PENUTUP}

Hasil dari penelitian ini dapat disimpulkan bahwa kata majemuk dalam teks berita daring CNN International edisi Sepember 2019 berdasarkan bentuknya yang terbagi menjadi bentuk tulisan dan bentuk kata majemuk. secara bentuk tulisan dalam penelitian ini, didapati bentuk tulisan close form (bentuk tertutup) yang ditulis sebagai kata tunggal dan open form (bentuk terbuka) yang ditulis sebagai kata terpisah. Kemudian, secara bentuk kata majemuk dalam penelitian ini didapati dua bentuk, yaitu endocentric compound (kata majemuk yang maknanya dapat di tentukan dari salah satu inti kata kata majemuk itu), dan exocentric compound, (kata majemuk yang benar-benar memiliki makna baru dan tidak mempertahankan makna asal atau tidak memiliki inti kata untuk menentukan makna itu). Berdasarkan kategorinya didapati kategori kata majemuk yang berkategori nomina nomina+nomina atau nomina+verba atau verba+nomina dan kategori verba yang terdiri atas nomina + verba.

Republika Online Edisi Maret-Mei: Suatu Kajian Sintaksis. Suar Betang, 13(2), 159--166.

Djajasudarma, F. (2010). Metode Linguistik Ancangan Metode Penelitian dan Kajian. Refika Aditama.

Halliday, M. A. K., \& Hasan, R. (1992). Bahasa, Konteks, dan Teks: Aspek- 
aspek Bahasa dalam Pandangan Semiotik Sosial. Gadjah Mada University Press.

Katamba, F., \& Stonham, J. (2006). Morphology. Palgrave Macmillan.

Lieber, R. (2007). Introducing to Morphology. Cambridge University Press.

O'Grady, W., \& Archibald, J. (2015). Contemporary Linguistic Analysis; An Intoduction. Library and Archives
Canada Cataloguing in Publication.

Plag, I. (2003). Word Formation In English. Cambridge University Press.

Santoso, A. (2012). Studi Bahasa Kritis: Menguak Bahasa Membongkar Kuasa. Penerbit Mandar Maju.

Sudaryanto. (2015). Metode dan Aneka Teknik Analisis Bahasa. Duta Wacana University Press.

Yule, G. (2016). The Study of Language. Cambridge University Press. 